\title{
Soil Fertility under Native Cerrado and Pasture in the Brazilian Savanna
}

\author{
Juliane Lilienfein, Wolfgang Wilcke, ${ }^{*}$ Lourival Vilela, Miguel Angelo Ayarza, \\ Samuel do Carmo Lima, and Wolfgang Zech
}

\begin{abstract}
In the Brazilian savanna, there is a risk that soil fertility of pastures declines to a level below that of the native savanna because of low fertilizer application. To evaluate biophysical pasture sustainability we compared regularly fertilized productive pasture (PP), degraded pasture fertilized $13 \mathrm{yr}$ previously (DP), and native savanna (Cerrado, CE) in an on-farm experiment. We determined (i) biomass productivity of the pastures and (ii) nutrient concentrations in Anionic Acrustoxes from three plots under each of CE, DP, and PP. From the 0to 2-m soil layer, we sampled solid phase in January 1998 and soil solution during two rainy seasons (1997-1998 and 1998-1999). The mean aboveground biomass production (dry weight) was $2.1 \mathrm{Mg} \mathrm{ha}^{-1}$ $\mathrm{yr}^{-1}$ for DP and 4.1 $\mathrm{Mg} \mathrm{ha}^{-1} \mathrm{yr}^{-1}$ for PP. In the solid phase of the 0- to $0.15-\mathrm{m}$ layer, mean total $\mathrm{N}$ and $\mathrm{S}$ and exchangeable $\mathrm{Ca}$ and Mg concentrations increased in the order $\mathbf{C E}<\mathbf{D P}<\mathbf{P P}$, while $\mathrm{NaHCO}_{3}$-extractable $\mathrm{P}$ was not significantly different among $\mathrm{CE}$, DP, and PP. In the soil solution at $0.15-\mathrm{m}$ depth, $\mathrm{pH}$ and concentrations of $\mathrm{Ca}$ and $\mathrm{Mg}$ also increased in the order $\mathrm{CE}<\mathrm{DP}<\mathrm{PP}$. At the 2-m depth, only $\mathrm{K}, \mathrm{Mn}$, and $\mathrm{NO}_{3}-\mathrm{N}$ concentrations in soil solution were slightly higher under the pastures than under $\mathrm{CE}$ indicating an increased risk of leaching losses to below the rooting zone. Thus, topsoil fertility in both pastures is increased compared with $\mathrm{CE}$, and little leaching occurs. Some fertility indicators in DP are still improved compared with CE 13 yr after a single fertilization.
\end{abstract}

$\mathrm{B}$ TWEEN 35 AND 40 million ha of the savanna region of Brazil, locally termed "Cerrado," are used as pastures. This area represents $80 \%$ of the total agriculturally used area in this region. Most pastures in the Brazilian CE were only established in the last three decades although there may have been some earlier grazing activity in the native CE. In general, after clearing of the natural savanna by harvesting the trees including their large roots, foreign pasture grass species were sown and fertilized at low rates (Spain et al., 1996; Lopes et al., 1999; Resck et al., 2000). The CE pastures supported a cattle herd of more than 52 million head in 1993 and thus represent an important component of the Brazilian agricultural production which may only be maintained or increased if pasture management is sustainable (Resck et al., 2000). To evaluate the biophysical sustainability we examined the productivity and soil fertility of different pastures.

The productivity of pastures may be measured as the

J. Lilienfein, Dep. of Environmental and Resource Sciences, MS 370, Univ. of Nevada-Reno, Reno, NV 89557; W. Wilcke, Dep. of Soil Science, Institute of Ecology, Berlin Univ. of Technology, Salzufer 11-12, D-10587 Berlin, Germany; W. Zech, Institute of Soil Science and Soil Geography, Univ. of Bayreuth, D-95440 Bayreuth, Germany; L. Vilela, EMBRAPA-Cerrados, Caixa Postal 08223, Planaltina-DF, Brazil; M.A. Ayarza, CIAT-LADERAS, Apartado 1410, Tegucigalpa, Honduras; S.d.C. Lima, Federal Univ. of Uberlândia, 38406-210 Uberlândia-MG, Brazil. Received 8 Sept. 2000. *Corresponding author (wolfgang.wilcke@tu-berlin.de).

Published in Soil Sci. Soc. Am. J. 67:1195-1205 (2003). dry matter production of the grass species at locations protected from grazing or as the liveweight gains of the cattle. Biomass production of fertilized Brachiaria decumbens Stapf pastures in the Brazilian CE ranges between 5.5 and $11 \mathrm{Mg} \mathrm{ha}^{-1} \mathrm{yr}^{-1}$ and liveweight gains between 487 and $771 \mathrm{~kg} \mathrm{ha}^{-1}$ at stocking rates of 2 to 2.5 animal units ha ${ }^{-1}$ (Kornelius et al., 1979; Cadisch et al., 1994). The grass biomass productivity of Brachiaria pastures in Brazil is substantially lower than in Australia where it may reach $33 \mathrm{Mg} \mathrm{ha}^{-1} \mathrm{yr}^{-1}$ (Whiteman et al., 1980). Furthermore, if the soils are not regularly fertilized the productivity declines rapidly after 4 to $10 \mathrm{yr}$ (Boddey et al., 1996).

The effects of forest clearing and subsequent pasture use on the fertility of the CE Oxisols has up to now only been studied by a few researchers (Lilienfein et al., 1998, 1999, 2000b; Neufeldt, 1998; Resck et al., 2000). Lilienfein et al. $(1998,2000 \mathrm{~b})$ found no significant differences in water-stable aggregate distribution and concentrations of total C, N, P, S, and Mo between the topsoils under native $\mathrm{CE}$ vegetation and pasture near the city of Uberlândia in the State of Minas Gerais. The distribution of $\mathrm{P}, \mathrm{S}$, and Mo among different chemical fractions did not differ between pasture soils and soils under native CE. From the same study area, Neufeldt (1998) reported a strong increase in soil organic $\mathrm{C}$ concentrations in pasture soils compared with the soils under native CE, particularly in the 50- to $2000-\mu \mathrm{m}$ particlesize fraction. Spain et al. (1996) found increased N concentrations under pasture than under native CE. The temporal course of the matric potentials as a measure for plant-available water and the mean water storage in soil under nonfertilized DP and under PP, which received maintenance fertilization were close to those of soils under native CE (Lilienfein et al., 1999).

For the Amazonian region, which has different climate but similar soils, more studies on the effect of pasture use on soil properties have been published. Cerri et al. (1991) and Feigl et al. (1995) observed decreasing $\mathrm{C}$ concentrations in surface soil after forest clearing in central Amazonas and Rondônia, respectively, which increased again after 1 to $2 \mathrm{yr}$ of pasture use, while Eden et al. (1991) did not observe a significant change in $\mathrm{C}$ concentrations in northern Roraima over time. Some authors reported increased $\mathrm{C}$ and $\mathrm{N}$ storage in surface soils after several years of pasture use compared with natural forest in eastern Amazonas and Rondônia (Feigl et al., 1995; Koutika et al., 1997). In the upper $1 \mathrm{~m}$ of an Oxisol under DP in Pará, Nepstad et al. (1994), in contrast, found reduced C storage compared with native rain forest. In the study of Eden et

Abbreviations: CE, Cerrado; DP, degraded pasture; ECEC, effective cation-exchange capacity; HSD, honest significant difference; PP, productive pasture; TOC, total organic C. 


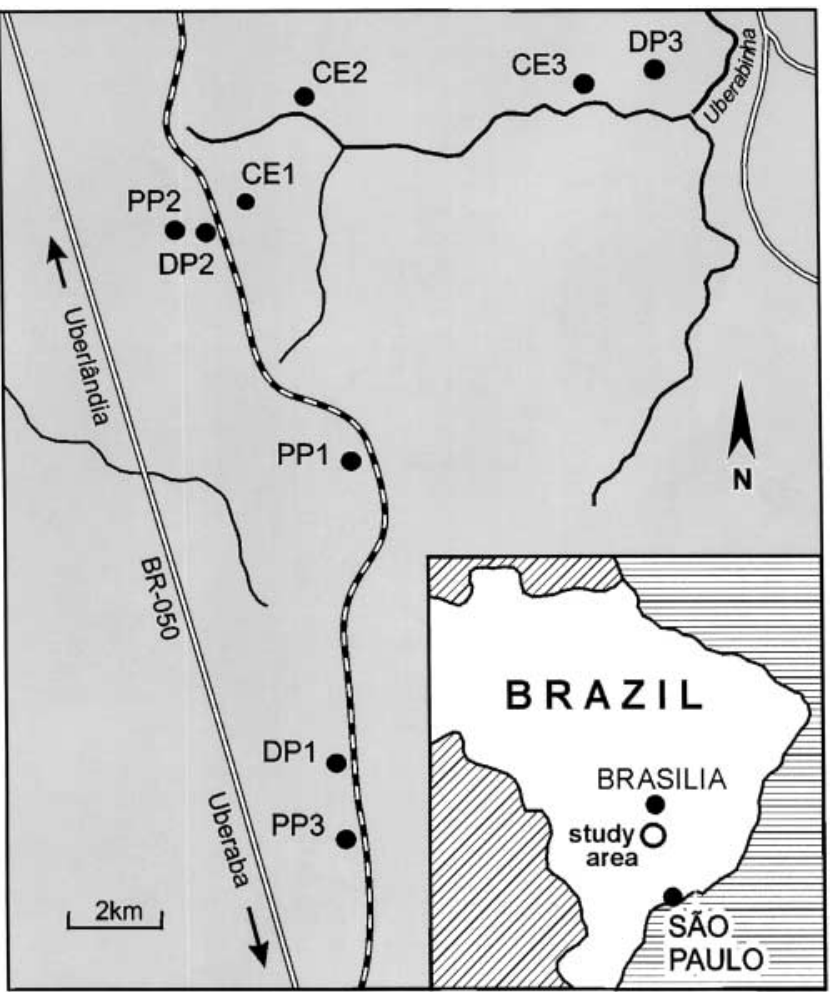

Fig. 1. Locations of the study sites.

al. (1991), basic cation concentrations in pasture surface soils fell below those of the natural forest soils after 12 yr of pasture use. Nepstad et al. (1994) have shown that a large part of the Amazonian rain forest relies on deep roots $(>8 \mathrm{~m})$ for water uptake during droughts. Changing the rooting depth by replacing the forest with the less deeply rooting pastures would reduce the deep soil C storage and alter the soil-water cycle. The effect would be more pronounced for productive pure grass pastures than for the so-called DPs containing some woody plants because of decreasing rooting depth in the order, forest $>$ DP $>$ pure grass pasture. These results illustrate that pasture use of tropical Oxisols may have contrasting effects on soil properties and that we are far from being able to draw generalized conclusions concerning the biophysical sustainability of pastures in the CE region.

Previous studies concerning land-use effects on the nutrient status of Oxisols in the CE showed that soil solution responds more sensitively to land use than the soil solid phase. The concentrations and chemical forms of $\mathrm{P}, \mathrm{S}, \mathrm{Mo}$, and metals in soil solid phase under natural savanna vegetation, Pinus plantation, and pastures were little affected by 10 to $20 \mathrm{yr}$ of land use (Lilienfein et al., 2000a, 2000b, 2001a). Metal concentrations in soil solution under Pinus plantations, however, were significantly increased indicating the beginning of soil acidification (Lilienfein et al., 2000a). Furthermore, dissolved $\mathrm{N}$ concentrations in soil solution under Pinus were significantly higher than under $\mathrm{CE}$ because of the accumulation of a deep organic layer with a high $\mathrm{N}$ storage (Lilienfein et al., 2001a). In the present study we examined soil solution properties under pastures because we believe that they are a sensitive indicator of land-use effects on soil fertility.

Our objective was to evaluate the productivity and soil fertility as indicators for biophysical sustainability of the pastures in the CE region near the city of Uberlândia in an on-farm experiment. We chose the two major pasture types of the region: a pure grass $\mathrm{PP}$ receiving regular maintenance fertilizing and a so-called DP, which was only fertilized at the date of establishment and is now characterized by partly vegetation-free soil and invasive $\mathrm{CE}$ plants. The biophysical sustainability of the pastures was assessed by examining (i) the biomass productivity, (ii) the fertility, that is, the nutrient concentrations in soil solid phase and solution, and (iii) the risk of nutrient losses to the deeper subsoil as indicated by the depth distribution and the temporal course of nutrient concentrations in soil solution at various depths. We assumed that the native savanna ecosystem is sustainable with respect to nutrient cycles and therefore compared the nutrient status and dynamics of the pasture soils with that of soils under native CE.

\section{MATERIALS AND METHODS}

\section{Study Sites}

The study was performed southeast of Uberlândia (State of Minas Gerais) about $400 \mathrm{~km}$ south of Brasília (195'S lat., $48^{\circ} 7^{\prime} \mathrm{W}$ long.). Mean annual temperature in Uberlândia between 1981 and 1990 was $22^{\circ} \mathrm{C}$ with only small variations between the coldest (June, July: $19^{\circ} \mathrm{C}$ ) and the warmest months (February: $24^{\circ} \mathrm{C}$ ). Mean annual precipitation during this period was $1550 \mathrm{~mm}$ with $130 \mathrm{~mm}$ during the dry season between May and September and $1420 \mathrm{~mm}$ during the rainy season between October and April (Rosa et al., 1991).

Within an area of about $100 \mathrm{~km}^{2}$, three plots of natural savanna (CE), DP, and PP were selected (Fig. 1). We tried to choose independent plots to allow for statistical evaluation with variance analysis (Lilienfein et al., 1999).

The native vegetation was classified as a typical CE according to the definition of Sarmiento (1984). It was characterized by an open grassland with a 15 to $40 \%$ cover of 3 - to 5 -m high trees. Tree density was 6487 ha $^{-1}$ with only 602 trees $\mathrm{ha}^{-1}$ taller than $2 \mathrm{~m}$. Dominant tree species in the layer $>2 \mathrm{~m}$ were Pouteria torta (Mart.) Radlk., Ouratea spectabilis (Mart.) Engl., Roupala montana Aubl., Byrsonima coccolobifolia H.B. et K., Dalbergia miscolobium Benth., Kielmeyera coriacea Mart., and Caryocar brasiliense Cambess, which together represented $70 \%$ of the biomass of the $>2$-m layer. In the 0.5 to 2-m tall tree layer, many different species were found of which Ouratea hexasperma (St.-Hil.) Baill. representing 33\% of the biomass in the 0.5 - to 2-m layer was most abundant. The dominant shrub species were Miconia holosericea DC., Hortia brasiliana Vand. ex DC., Myrcia rostrata DC., Parinari obtusifolia Hook. f., and Campomanesia velutina Blume, contributing $93 \%$ to the total shrub biomass. Among the grass species we most frequently found Andropogon Minarum Kunth, Axonopus barbigerus (Kunth) Hitchc., Tristachya chrysothrix Nees, and Echinolaena inflexa (Poir.) Chase of the family Poaceae, which comprised the highest number of species; among the herbaceous species, members of the families Asteraceae, Rubiaceae, Fabaceae, and Mimosaceae were most abundant.

The most important criteria for the selection of the pasture plots were the current visual impression and the likelihood 
that the pasture use followed directly the clearing of the native vegetation. The DP sites showed the characteristics Lopes et al. (1999) described as typical for degraded pastures of the $\mathrm{CE}$ region: decreased grass cover compared with the PPs, followed by the invasion of CE plants. The PP, in contrast, was a pure grass pasture of Brachiaria decumbens Stapf with a closed vegetation cover. The history of the pastures was reconstructed by interviewing the current landowners. Because of changes in land ownership and the lack of written documentation, this reconstruction was not easy and may not be entirely reliable, although we only selected the pastures with the best-known history. However, we do not see how this problem may be overcome when attempting to conduct an on-farm study in a rapidly developing tropical country. All pastures under study were established by harvesting the native $\mathrm{CE}$ vegetation including the large roots. They were established around 1985. The most common procedure was to plant upland rice (Oryza sativa L.), which was fertilized with about $40 \mathrm{~kg}$ $\mathrm{P}, 65 \mathrm{~kg} \mathrm{~K}, 32 \mathrm{~kg} \mathrm{~N}$, and $1 \mathrm{Mg}$ of dolomitic limestone ha ${ }^{-1}$. The fertilizer was mixed with seeds of Brachiaria decumbens, an imported grass species from Africa. After the harvest of the rice, the Brachiaria was already stabilized and grazing began. In 1996-1997, we fertilized all PP replicates with $17 \mathrm{~kg}$ $\mathrm{P} \mathrm{ha}{ }^{-1}$ and $33 \mathrm{~kg} \mathrm{~K} \mathrm{ha}^{-1}$. One of the three replicates of PP, PP1 in Fig. 1, was an experimental pasture where the fertilizing rates are well known. The pasture PP1 received $17 \mathrm{~kg} \mathrm{P}$ and $33 \mathrm{~kg} \mathrm{~K} \mathrm{ha}^{-1}$ at 4-yr intervals (i.e., in 1988, 1992, and 1996). The other PP replicates received maintenance fertilizer applications at similar but unknown rates and application dates. Soils at all sites were very-fine isohyperthermic Anionic Acrustoxes (Soil Survey Staff, 1997) or Latossolos vermelhos escuros and Latossolos vermelhos-amarelos according to the Brazilian soil classification and had similar chemical and physical properties before the beginning of land-use (Lilienfein et al., 1999). All soils were developed from the same geological parent material, fine limnic sediments of the lower Tertiary. The clay content of the soils ranged between 615 to $885 \mathrm{~g}$ $\mathrm{kg}^{-1}$. Properties, which are typically not influenced by land use such as soil classification, particle-size distribution, and the concentrations of dithionite-soluble Fe (Holmgren, 1967) and oxalate-soluble Al (Schwertmann, 1964) were not significantly different among the studied soils (Lilienfein et al., 1999).

\section{Equipment and Sampling}

On each of the nine plots, a 10 by $10 \mathrm{~m}$ area was fenced and equipped with five replicate tensiometers and suction cups at each of 0.15-, 0.3-, 0.8-, 1.2-, and 2-m soil depths. The major constituents of the porous cups were $\mathrm{Al}_{2} \mathrm{O}_{3}(70 \%)$ and $\mathrm{SiO}_{2}$ $(29 \%)$ with a mean pore diameter of $1 \mu \mathrm{m}$. Soil solution samples were collected with permanent under-pressure produced by vacuum pumps. The under-pressure was adjusted weekly according to the current matric potentials measured with the tensiometers. The soil solutions collected with the five suction cups of a plot were combined into one sample for each depth. Soil solution was sampled and tensiometers were read weekly during two rainy seasons (14 Oct.-28 Apr. 1997-1998 and 1998-1999).

At all nine plots, one composite soil sample from the 0 - to 0.15-, 0.15- to 0.3-, 0.3- to 0.8-, 0.8- to 1.2-, 1.2- to 2-m layers was taken in January 1998. Within each plot, samples from the 0 - to $0.15-\mathrm{m}$ layer were taken from five locations and combined, while those of the deeper layers were taken from one soil pit on each plot. Soil bulk density was determined gravimetrically using $100-\mathrm{mL}$ soil cores taken in five-fold replication per layer. All samples were dried at $40^{\circ} \mathrm{C}$ and sieved to $<2 \mathrm{~mm}$.
The $\mathrm{pH}$ of the soil solutions was measured in a subsample immediately after sampling with a standard $\mathrm{pH}$ electrode (U 402-S7, Orion, Boston, MA) in a separate aliquot, which was afterwards discarded. The remaining solutions were frozen for storage.

The following properties were determined in the solid soil samples: $\mathrm{pH}$ with a standard glass electrode in $\mathrm{H}_{2} \mathrm{O}$ and $1 \mathrm{M}$ $\mathrm{KCl}$, soil/solution ratio $1: 2.5$, total concentrations of $\mathrm{C}, \mathrm{N}$, and $\mathrm{S}$ by dry combustion and gas chromatographic separation with a CNS analyzer (Elementar Vario EL, Elementar Analysensysteme $\mathrm{GmbH}$, Hanau, Germany), exchangeable cations by extraction with $1 M$ ammonium acetate (Sumner and Miller, 1996). The soil water content was estimated from the matric potentials - measured with tensiometers - with the help of the soil water characteristic curve as described by Lilienfein et al. (1999).

In soil solutions and extracts, we determined the concentrations of $\mathrm{Ca}, \mathrm{Fe}, \mathrm{K}, \mathrm{Mg}$, and $\mathrm{Na}$ with flame atomic absorption spectrometry (SpectrAA 400, Varian, Mulgrave, Australia). Aluminum, $\mathrm{Mn}$, and $\mathrm{Zn}$ concentrations in soil solution were measured with inductively coupled plasma mass spectroscopy (VG PlasmaQuad PQ2 Turbo Plus, VG Elemental, Windsford, UK) and in extracts with flame atomic absorption spectrometry, $\mathrm{NH}_{4}$ and $\mathrm{NO}_{3}$ with a rapid flow analyzer (RFA-300, Alpkem Corporation, Clackamas, OR), total organic C (TOC) with an automatic TOC analyzer (TOC-5050, Shimadzu Corporation, Tokyo, Japan), and total $\mathrm{S}$ and $\mathrm{P}$ with inductively coupled plasma-atomic emission spectroscopy (ICP-AES, GBC Integra XMP, GBC Scientific Equipment Pty, Ltd., Dandenong, Victoria, Australia).

\section{Grass Biomass Production}

The grass biomass production of the pastures was determined by harvesting the total aboveground biomass of three replicate $0.5 \mathrm{~m}^{2}$ large subplots on six dates between 29 Oct. 1997 and 12 Apr. 1999 at all pasture plots. On each sampling date subplots were chosen for biomass determination. Biomass samples were collected at the beginning of the rainy season in October or November, in January or February, and at the end of the rainy season in April. After biomass sampling, all grass inside the fenced area was cut to the same mean height as outside to simulate grazing. The samples were dried to constant weight at $70^{\circ} \mathrm{C}$ and masses were determined gravimetrically. The productivity was calculated by difference of the aboveground biomass between two dates and addition of the biomass harvested per area of the subplot to simulate grazing.

\section{Data Evaluation}

To evaluate the effect of pasture management on nutrient availability to plants and nutrient leaching we compared the mean depth distribution and the temporal course of selected soil solution properties between CE, DP, and PP. The examined properties include the $\mathrm{pH}$ and the concentration of TOC $(<80 \mu \mathrm{m}$, i.e., in the solution that passed the ceramic cups without further filtration). We consider solution TOC to be an index of dissolved and particulate organic matter, which may be important nutrient carriers (Kalbitz et al., 2000), as well as a source of nutrients and potentially toxic Al (Savory and Wills, 1991).

To enable data evaluation with the help of ANOVA we tested the three following prerequisites of the statistical design of our study. The first prerequisite is that all study sites had homogeneous soil properties before land use, which we showed above. The second prerequisite is that the study sites are independent. We are sure that this is the case because all 
study sites are separated from each other by areas with other land use and because the distance of several $100 \mathrm{~m}$ between the plots is larger than geostatistical ranges of the studied soil properties. The third prerequisite is random location within the homogeneous study area. This prerequisite was most difficult to meet because we had to use existing land-use systems in our on-farm experiment. Although we may not rule out that there were site-specific reasons for the establishment of a given land use, the homogeneity of the soil suggests that random ownership was more important than soil quality. Therefore, we concluded that the prerequisites for applying ANOVA were met.

Mean values of the soil parameters were tested for differences between CE, DP, and PP by using Tukey's honest significant difference (HSD) mean separation test (Hartung and Elpelt, 1989). To compare mean nutrient concentrations in the soil solution between the systems and between the various depths of one system, the Wilcoxon matched-pairs test was used. Significance was set at $P<0.05$ for Tukey's HSD test and at $P<0.01$ for the Wilcoxon matched-pairs test because of the high number of compared values. Correlation analyses between soil water content and nutrient concentrations in soil solution were performed using the Least Squares method (Hartung, 1989). Statistical analyses were performed with STATISTICA for Windows 5.1 (StatSoft, 1995, Loll and Nielsen, Hamburg, Germany).

\section{RESULTS AND DISCUSSION Productivity}

The mean aboveground dry grass biomass production during the two monitored years was $2.1 \pm 0.4 \mathrm{Mg} \mathrm{ha}^{-1}$ $\mathrm{yr}^{-1}$ for DP and $4.1 \pm 1.6 \mathrm{Mg} \mathrm{ha}^{-1} \mathrm{yr}^{-1}$ for PP. This was lower than the range of productivities in new but unfertilized Brazilian Brachiaria decumbens pastures of 5.5 to $12 \mathrm{Mg} \mathrm{ha}^{-1} \mathrm{yr}^{-1}$ reported in the literature (Kornelius et al., 1979; Cadisch et al., 1994). Liveweight gains were only determined for PP1 where $414 \mathrm{~kg} \mathrm{ha}^{-1} \mathrm{yr}^{-1}$ at a stocking rate of 1.0 animal units ha ${ }^{-1}$ (one animal unit $=450 \mathrm{~kg}$ liveweight, Cadisch et al., 1994) were observed of which 324 were reached during the rainy season and 90 during the dry season. This was also lower than the range of 487 to $771 \mathrm{~kg} \mathrm{ha}^{-1} \mathrm{yr}^{-1}$ reported in the literature (Kornelius et al., 1979; Cadisch et al., 1994) but corresponds well with the lower grass biomass production rate. Commonly, a decrease in annual liveweight gains by $50 \%$ is observed within $3 \mathrm{yr}$ after fertilization (L. Vilela, Embrapa Cerrados, personal communication, 1997). Therefore, we estimated that liveweight gains in the DP systems were about $50 \%$ of those in the PP systems which was reflected by a mean stocking rate of 0.6 animal units ha ${ }^{-1}$ in the DP systems. Although the PP systems were more heterogeneous with respect to their grass biomass productivity as indicated by a coefficient of variation of $39 \%$ between the three replicate sites compared with the DP systems $(17 \%)$, we consider the productivity of both pasture systems as sufficiently homogeneous among their replicates to draw generalized conclusions for these two typical pasture systems of the savanna region around Uberlândia. The similar biomass productivity among the replicates of the different pasture systems also indicates similar nutrient inputs into the replicate soils since 1985. In the
$\mathrm{CE}$, the standing biomass of the green grass layer in January, when the biomass had reached its maximum, was $0.9 \mathrm{Mg} \mathrm{kg}^{-1}$ and that of the herbs was $0.1 \mathrm{Mg} \mathrm{kg}^{-1}$ (Lilienfein et al., 2001b). During the period of our study, we observed little grazing activity in the CE and therefore did not determine grass productivity.

\section{Soil Fertility: Soil Solid Phase Properties}

Soil $\mathrm{pH}$ determines the plant-availability of many nutrients. In Oxisols, particularly the $\mathrm{P}$ availability is reduced because of strong sorption to oxides at $\mathrm{pH}<5$ (Goedert, 1983; Tiessen and Moir, 1993; Friesen et al., 1997). The $\mathrm{pH}$ of the study soils is controlled by the buffering of $\mathrm{Al}$ oxides, which is typical for Oxisols (Ulrich, 1981; Goedert, 1983; Driessen and Dudal, 1989, Table 1). The mean $\mathrm{pH}\left(\mathrm{H}_{2} \mathrm{O}\right.$ and $\left.\mathrm{KCl}\right)$ in the upper $0.3 \mathrm{~m}$ was higher under PP than under DP and $\mathrm{CE}$ because of the higher application rate of dolomitic limestone. However, the differences in mean $\mathrm{H}$ activity of the equilibrium soil extracts among the three systems were not significant except for that in the $\mathrm{KCl}$ extract at 0.3 - to $0.8-\mathrm{m}$ soil depth between DP and CE. In all soils, the $\mathrm{pH}$ increased with depth, except the $\mathrm{pH}\left(\mathrm{H}_{2} \mathrm{O}\right)$ under PP, indicating the surface acidification. In the topsoil, the $\mathrm{pH}\left(\mathrm{H}_{2} \mathrm{O}\right)$ was higher than the $\mathrm{pH}(\mathrm{KCl})$ while in the subsoil the reverse was true. The reason for this observation is that in the subsoil positive charges dominate because of low organic matter and high oxide concentrations (Driessen and Dudal, 1989).

At 0 - to $0.15-\mathrm{m}$ soil depth, mean $\mathrm{C}$ concentrations were higher under PP than under DP and CE, although the differences were not significant (Lilienfein et al., 1999). Mean N and S concentrations were higher under both pasture systems at all depths than under CE. However, differences in mean $\mathrm{N}$ concentrations between $\mathrm{CE}$ and DP and between CE and PP were only significant at 1.2- to 2-m depth and between CE and PP at 0.3 to $0.8 \mathrm{~m}$. Higher $\mathrm{N}$ concentrations under pasture than under CE in the Brazilian savanna have also been observed by Spain et al. (1996). The differences in mean S concentrations between CE and PP and between CE and DP were significant except at 0.15 - to $0.3-\mathrm{m}$ depth. In a previous study, samples were taken from the same plots at the end of the rainy season in April 1997. We did not detect significant differences in mean total $\mathrm{S}$ concentrations of the 0 - to $0.15-\mathrm{m}$ layer between CE, DP, and PP (Lilienfein et al., 2000b). This may be the result of a large spatial variability or of a temporal variation in total S concentrations. In the same previous study, we found that mean total $\mathrm{P}$ and $\mathrm{NaHCO}_{3}$-extractable $\mathrm{P}$ concentrations in surface soil (0-0.15 m depth) were not significantly different between the three systems (CE: 388/17.6 mg kg ${ }^{-1}$, DP: 341/16.9, PP: 333/20.9), although mean $\mathrm{P}$ concentrations under the pastures were lower. This indicates $\mathrm{P}$ export by grazing if the assumption of similar native $\mathrm{P}$ concentrations in all studied soils is true. In all soils of the present study, C, N, and S concentrations decreased with increasing depth.

Similar C concentrations and higher $\mathrm{N}$ and S concentrations in soils under pasture than under CE result in 
smaller $\mathrm{C} / \mathrm{N}$ and $\mathrm{C} / \mathrm{S}$ ratios under pasture than under $\mathrm{CE}$. Increased $\mathrm{N}$ concentrations in the subsoil and narrowing $\mathrm{C} / \mathrm{N}$ ratios were also found in soils under Pinus caribaea Morelet plantations in the same region when compared with soils under CE (Lilienfein et al., 2001a). However, the subsoil accumulation of $\mathrm{N}$ was less pronounced in the pasture soils than under Pinus. The result indicates that under the pastures, like under Pinus, $\mathrm{NO}_{3}^{-}$was leached from the surface soil to greater depth where it was stored, probably because of sorption to positively charged surfaces (Morais et al., 1976). Thus, pasture use results in the formation of a subsoil $\mathrm{N}$ reservoir, which still may be recycled to the surface by plants. Similar observations have been made in the Amazonian region by Cahn et al. (1992) for Oxisols under corn and by Schroth et al. (1999) for Oxisols under mixed tree plantations.

At the 0 - to $0.3-\mathrm{m}$ soil depth, the mean effective cation-exchange capacity (ECEC) increased significantly in the order, $\mathrm{CE}<\mathrm{DP}<\mathrm{PP}$. This was the result of the increasing $\mathrm{pH}$ along the same line. In the same depth layer, mean exchangeable $\mathrm{Ca}$ and $\mathrm{Mg}$ concentrations also followed the trend $\mathrm{CE}<\mathrm{DP}<\mathrm{PP}$ reflecting the different fertilization rates. However, at soil depths $>0.3 \mathrm{~m}$, there were no significant differences in mean ECEC and mean exchangeable $\mathrm{Ca}$ and $\mathrm{Mg}$ concentrations between the three systems. Thus, the fertilizer effect was restricted to the topsoil. Mean exchangeable $\mathrm{Al}, \mathrm{Fe}, \mathrm{K}$, and $\mathrm{Na}$ concentrations did not differ significantly between the three systems at any depth.

Our results indicate that $13 \mathrm{yr}$ after fertilization, the fertility of the DP soils was still higher than that of the CE soils. To illustrate this, we calculated the storage of $\mathrm{N}, \mathrm{S}$, exchangeable $\mathrm{Ca}$, and exchangeable $\mathrm{Mg}$ in the upper 0.3-m layer of the studied systems (Fig. 2). Thus, in contrast to some pastures of the Amazonian region (Eden et al., 1991), the fertility of the DP did not drop to below that of the native system during the monitored period.

\section{Soil Fertility: Soil Solution Properties}

Nutrients in soil solution are readily plant-available. Therefore, topsoil solution properties may be used as an indication of nutrient availability to plants because most roots are concentrated in the A horizons. Subsoil solution properties, in contrast, are indicative of the risk of nutrient losses to below the rooting zone although it is not possible to infer nutrient fluxes directly from nutrient concentrations because of possible differences in soil water contents.

The mean soil solution $\mathrm{pH}$ during the two rainy seasons increased with increasing soil depth under CE and PP and only varied little with increasing depth under DP (Fig. 3a). Under PP, the mean soil solution $\mathrm{pH}$ was significantly higher at the $0.15-\mathrm{m}$ than at the $0.3-\mathrm{m}$ depth, which was the result of the recent application of dolomitic limestone. Furthermore, the mean soil solution $\mathrm{pH}$ was significantly higher under PP than under CE and DP at all depths because of the regular maintenance fertilization. There were no significant differences in

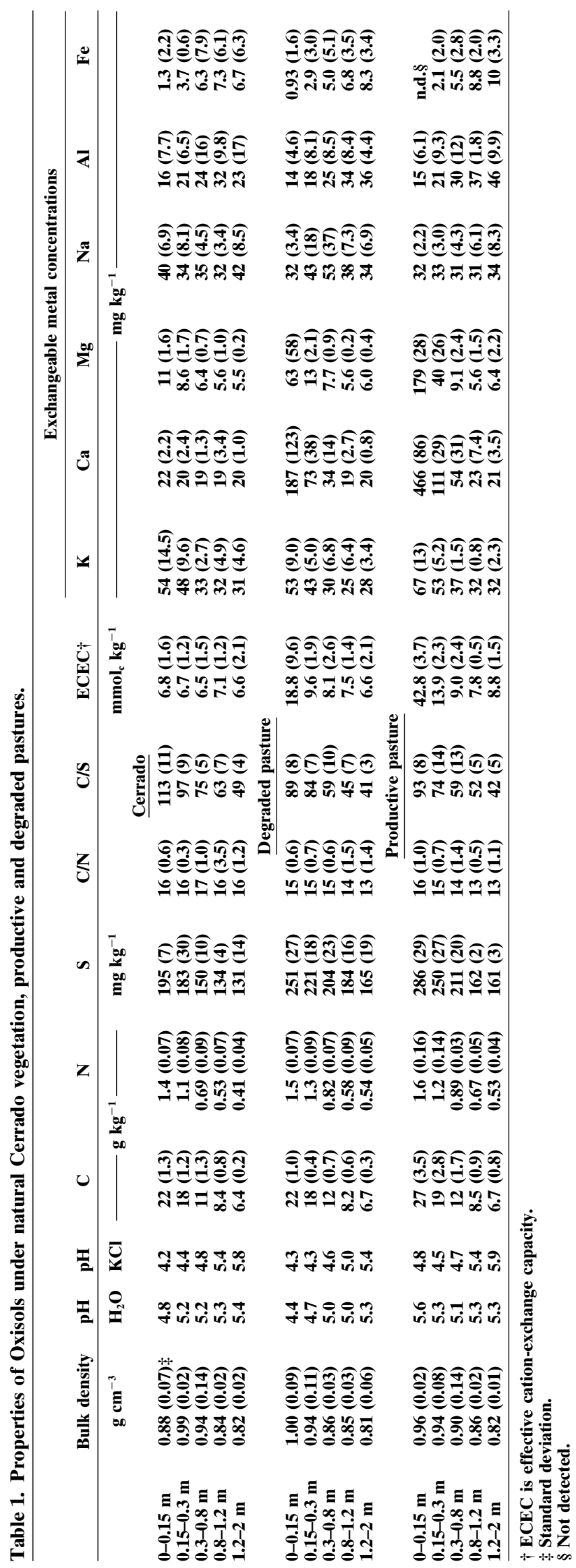




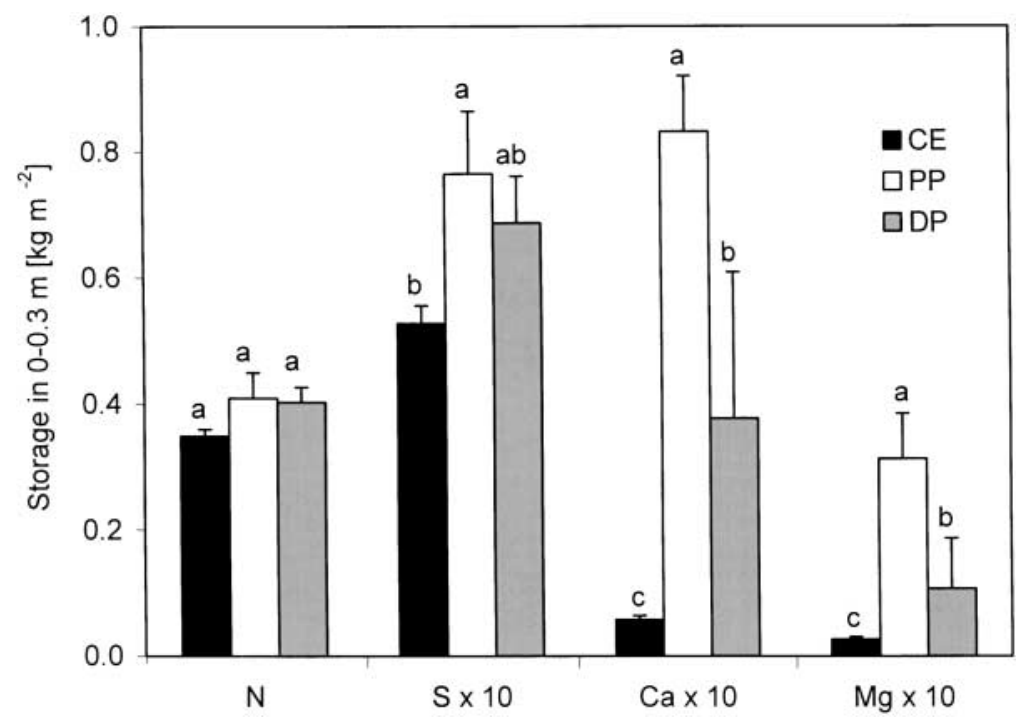

Fig. 2. Mean storage of $\mathrm{N}, \mathrm{S}$, exchangeable Ca, and exchangeable $\mathrm{Mg}$ in the uppermost $0.3-\mathrm{m}$ layer under Cerrado (CE), degraded (DP) and productive (PP) pastures in January 1998. The error bars represent standard deviations $(n=3)$, different letters indicate significant differences according to Tukey's honest significant difference (HSD) test $(P<0.05)$. The S, Ca, and Mg concentrations are tenfold magnified.

mean soil solution $\mathrm{pH}$ between DP and CE except at the 2-m depth, where $\mathrm{pH}$ was significantly higher under DP. The result indicates that the effect of the initial application of dolomitic limestone has reached $2 \mathrm{~m}$ depth after $13 \mathrm{yr}$.

Under CE, mean TOC concentrations were higher at the 0.15-m depth than between the 0.3- and 2-m depths where no further changes with depth were observed (Fig. 3b). Under PP, highest TOC concentrations were also found in the surface soil solution at 0 - to $0.3-\mathrm{m}$ depth. Under DP, in contrast, TOC concentrations were lowest at the $0.15-\mathrm{m}$ depth and tended to increase with increasing soil depth. Highest TOC concentrations in the surface soil solution under CE and PP may be the result of the higher rooting density under PP possibly releasing more organic compounds and the partly developed organic layer in the $\mathrm{CE}$ from which TOC may be leached into the mineral soil. Low TOC concentrations in the soil solution of all three systems $(4.3-6.9 \mathrm{mg}$ ) when compared with those of temperate soils indicate that TOC is strongly sorbed to the soil matrix because of the high concentrations of $\mathrm{Fe}$ and $\mathrm{Al}$ oxides in Oxisols (Davis, 1982; McKnight et al., 1992; Gu et al., 1994). Currie et al. (1996) for example detected three to five times higher TOC concentrations in a temperate hardwood forest in soil solution collected at the $0.6-\mathrm{m}$ depth of a Dystrochrept. The assumption of strong TOC sorption to the mineral soil is supported by the finding that litter leachate under Pinus caribaea plantations in the same region contained high TOC concentrations which was to a large extent sorbed to the soil solid phase in the upper $0.15 \mathrm{~m}$ of the mineral soil (Lilienfein et al., 2001a). Under DP, the TOC concentrations were higher than those under CE and PP at all depths between 0.3 and $2 \mathrm{~m}$. The differences in mean TOC concentrations were significant at the 0.8 - to $1.2-\mathrm{m}$ depth and between DP and CE additionally at the $0.3-\mathrm{m}$ depth. This indi- cates that more TOC is leached to below 2-m depth under DP than under CE and PP.

Under $\mathrm{CE}, \mathrm{NO}_{3}$ concentrations in soil solution were higher in the upper $1 \mathrm{~m}$ of the soil than between 1 - and 2-m depths; under PP and DP the converse was true (Fig. 3c). Nitrate concentrations in soil solution were low under all of the studied systems and often below the detection limit of $0.01 \mathrm{mg} \mathrm{NO}_{3}-\mathrm{N} \mathrm{L}^{-1}$. Nitrate concentrations in all soils of our study were below the mean of $1 \mathrm{mg} \mathrm{NO}_{3}-\mathrm{N} \mathrm{L}^{-1}$ that Uhl and Jordan (1984) reported for unfertilized forest soils in the Amazonian basin of Venezuela. Differences between PP and CE and between DP and CE were only significant at the 1.2- and $2-\mathrm{m}$ depth. The result indicates that, under the pastures, the $\mathrm{NO}_{3}$ availability in the surface horizon was not changed compared with the $\mathrm{CE}$ while $\mathrm{NO}_{3}$ was leached to greater soil depth. Thus, $\mathrm{N}$ losses from the rooting zone may be expected in spite of the increased $\mathrm{NO}_{3}$ sorption to positively charged surface sites in the subsoil. Ammonium, $\mathrm{P}$, and $\mathrm{S}$ concentrations in soil solution were below the detection limits of $0.01 \mathrm{mg} \mathrm{NH}_{4}^{+}-\mathrm{N} \mathrm{L}^{-1}$, $0.2 \mathrm{mg} \mathrm{P} \mathrm{L}^{-1}$, and $0.3 \mathrm{mg} \mathrm{S} \mathrm{L}^{-1}$ in all samples.

Under $\mathrm{PP}$, mean $\mathrm{K}, \mathrm{Ca}$, and $\mathrm{Mg}$ concentrations decreased with increasing soil depth (Fig. 3d-f). Under $\mathrm{CE}$ and DP, mean Ca concentrations also decreased with increasing soil depth, mean $\mathrm{K}$ concentration decreased between the 0.15- and 0.3-m depth and increased at greater depth, and mean $\mathrm{Mg}$ concentration varied little with depth. Increased nutrient concentrations in surface soil solution may be the result of fertilizing and nutrient cycling by plants. Except for the $\mathrm{Ca}$ concentrations in the topsoil solution of PP, all base metal concentrations were at the lower boundary of nutrient concentrations reported for unfertilized tropical forests soils of 0.4 to $1.4 \mathrm{mg} \mathrm{K} \mathrm{L}^{-1}, 0.4$ to $2.5 \mathrm{mg} \mathrm{Ca}$ $\mathrm{L}^{-1}$, and 0.1 to $0.2 \mathrm{mg} \mathrm{Mg} \mathrm{L}^{-1}$ (Steinhardt, 1979; Jordan, 1982; Hölscher, 1995). The concentrations of Ca, K, and 

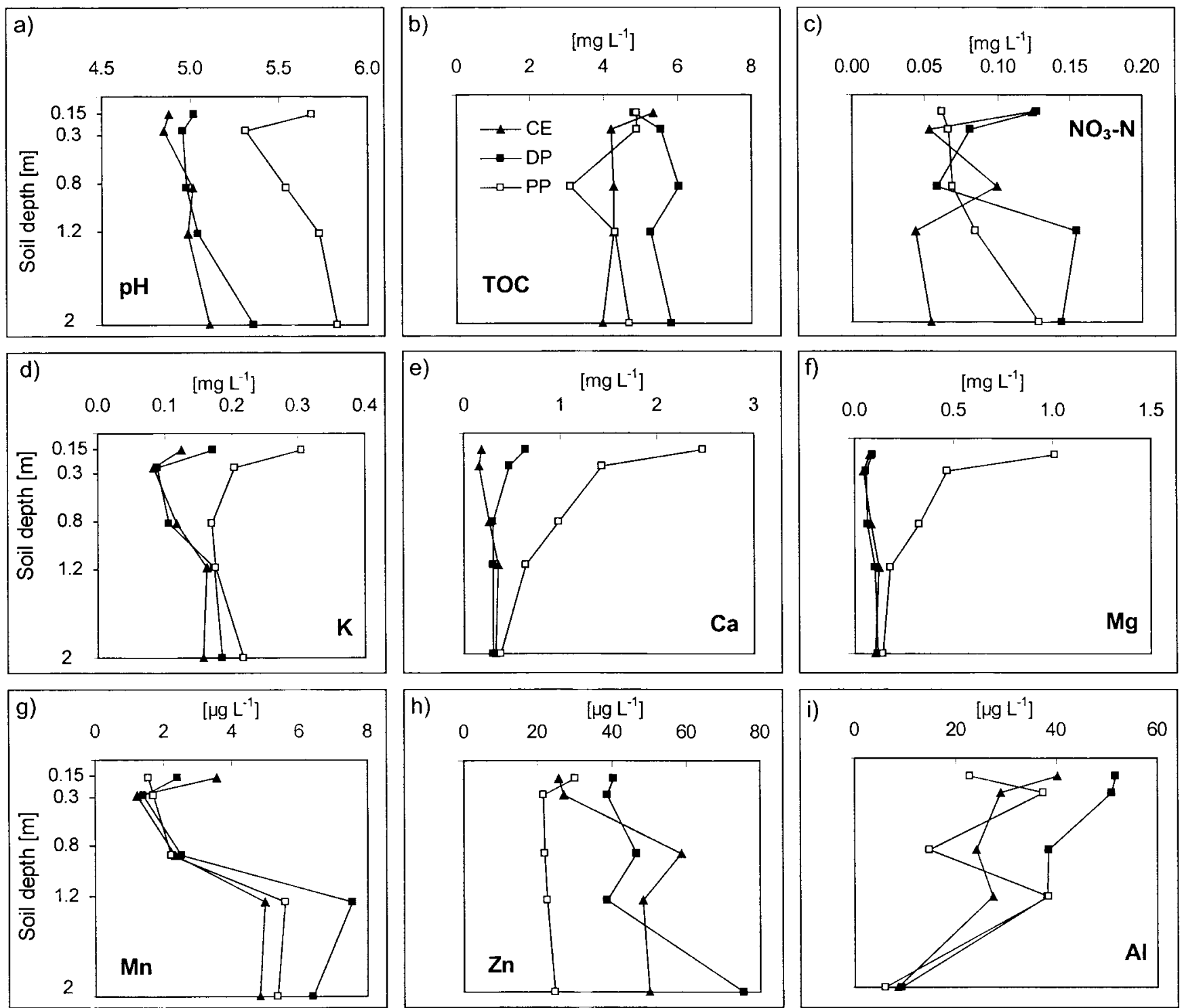

Fig. 3. (a) Mean pH and (b) concentrations of total organic $\mathrm{C}$ (TOC), (c) $\mathrm{NO}_{3}-\mathrm{N}$, (d) $\mathrm{K}$, (e) $\mathrm{Ca}$, (f) $\mathrm{Mg}$, (g) $\mathrm{Mn}$, (h) $\mathrm{Zn}$, and (i) $\mathrm{Al}$ in soil solution at the 0.15-, 0.3-, 0.8-, 1.2-, and 2-m depth of Cerrado (CE), degraded (DP), and productive (PP) pastures between 14 Oct. and 28 Apr. 19971998 and 1998-1999.

$\mathrm{Mg}$ were higher under PP than under CE and DP at all soil depths. Potassium concentrations of Replicate 1 of DP (DP1) at the 2-m soil depth were consistently higher (on average: $0.6 \mathrm{mg} \mathrm{L}^{-1}$ ) than those of DP2 (0.23) and DP3 (0.15). Under DP1, K concentrations at the 2-m depth were also consistently higher than at the $1.2-\mathrm{m}$ depth (0.12). We cannot explain the increase in $\mathrm{K}$ concentrations between the 1.2- and 2-m soil depth under DP1, but as this was only observed in one of the three plots, the K concentrations at the 2-m soil depth under DP shown in Fig. 3d only represent the mean of the values under DP2 and DP3. Increased $\mathrm{Ca}, \mathrm{K}$, and $\mathrm{Mg}$ concentrations in the surface soil solution under PP and increased $\mathrm{Ca}$ and $\mathrm{K}$ concentrations under DP than under CE illustrate the increased fertility of both pasture types. The differences in base metal concentrations were much smaller at the 2-m depth than in the surface soil solution indicating that little leaching occurred.
The depth distribution of mean Mn concentrations in soil solution was similar in all three studied systems (Fig. 3g). Manganese concentrations decreased between 0.15 and $0.3 \mathrm{~m}$ soil depth, increased between 0.3 and $1.2 \mathrm{~m}$ and did not change between 1.2 and $2 \mathrm{~m}$. Manganese concentrations reported as typical for tropical forest soils of 11 to $77 \mu \mathrm{g} \mathrm{L}^{-1}$ (Steinhardt, 1979; Jordan, 1982; Hölscher, 1995) were higher than Mn concentrations in our study. Between the 0.8- and 2-m depth, Mn concentrations under DP were significantly higher than under $\mathrm{CE}$ and between the 1.2- and 2-m depths also than under PP. This indicated a higher risk of Mn-leaching losses possibly associated with TOC under DP than under the other systems.

Mean $\mathrm{Zn}$ concentrations tended to increase with depth under CE and DP while, under PP, the highest mean $\mathrm{Zn}$ concentration was observed at the $0.15-\mathrm{m}$ soil depth (Fig. 3h). Under PP, Zn concentrations decreased 
between the 0.15- and 0.3-m depths but did not vary much between the 0.3- and 2-m depths. Mean $\mathrm{Zn}$ concentrations under PP were significantly lower than under DP at all soil depths and than under CE at the 0.8to 2-m depth. Lower $\mathrm{Zn}$ concentrations in soil solution under PP than under DP and CE were probably caused by the higher solution $\mathrm{pH}$ under PP and therefore reduced Zn solubility (Brümmer et al., 1986). Higher Zn concentrations at $2 \mathrm{~m}$ depth under DP may, like those of $\mathrm{Mn}$, reflect the higher TOC concentrations. Thus, under PP the $\mathrm{Zn}$ availability in the topsoil is not different than under $\mathrm{CE}$ while $\mathrm{Zn}$ losses to the deeper subsoil are reduced. Under DP, both Zn availability in the topsoil and the risk of $\mathrm{Zn}$ losses to the deeper subsoil are increased compared with $\mathrm{CE}$.

Mean concentrations of the potentially toxic $\mathrm{Al}$ in soil solution were highly variable, which may be partly attributable to concentrations close to the detection limit (Fig. 3i). As we set all values below the detection limit to zero, the presented $\mathrm{Al}$ concentrations are an underestimation. Under DP, mean Al concentrations were higher than under $\mathrm{CE}$ down to the 1.2-m depth and than under PP down to the 0.8-m depth although not all differences were significant. As solution $\mathrm{pH}$ under CE and under DP was similar, higher Al concentrations under DP than under CE may only be explained by higher concentrations of TOC under DP and therefore more dissolved organocomplexes of $\mathrm{Al}$ (Vance et al., 1996). Thus, even the increased Al concentration would not result in an increased toxicity risk, because organocomplexes of Al are not toxic (Savory and Wills, 1991). Lowest Al concentrations of all three systems were observed at the 2-m soil depth. Similar findings were reported for the Pinus plantations in the same region (Lilienfein et al., 2000a) that can be explained by increasing soil solution $\mathrm{pH}$ and therefore decreasing $\mathrm{Al}$ solubility with increasing soil depth (Jardine and Zelazny, 1996).

In all systems, the element concentrations in soil solution at the beginning of the rainy season were higher at all depths than during the high rainy season. This effect is shown for selected elements in Fig. 4. Increased element concentrations may be explained by dissolution of salts accumulated during the dry season and by mineralization of organic matter when the soil was rewetted that released soluble organic compounds, metal cations, N, P, and S (Birch, 1958; Sørensen, 1974; Matzner and Thoma, 1983). Similar results were reported for the temporal course of nutrient concentrations under Pinus plantations (Lilienfein et al., 2000a, 2001a). Thus, largest leaching losses have to be expected at the beginning of the rainy season when element concentrations in soil solution are highest but plant uptake is still limited. At this time, the soil water content at the 2-m depth increased in the order, $\mathrm{CE}<\mathrm{PP}<\mathrm{DP}$ (Lilienfein et al., 1999). Figure 4 illustrates that the "first flush" effect was more pronounced for base metals under PP than under DP and CE.

The average soil-water contents at the $0-$ to $15-\mathrm{cm}$ soil depth during the two rainy seasons for CE, DP, and PP were 310, 311, and $325 \mathrm{~g} \mathrm{H}_{2} \mathrm{O} \mathrm{kg}^{-1}$, respectively, but they varied over a wide range during the monitored period (Fig. 4). Consequently, the changes in element concentrations of the soil solution during the monitored period may partly have been caused by variations in the soil water content. To evaluate the importance of the variations in soil water content for element concentrations we ran correlation analyses between the soil water contents and element concentrations of the soil solution. Generally, $<40 \%$ of the variability in element concentrations of the soil solution may be explained by variations in soil water content. However, in 22 of 135 correlations, the correlation coefficients were significant. This was mainly true for the relationship between the soil water content and the concentrations of TOC (nine cases) and between the soil water content and $\mathrm{pH}$ (three cases). However, for only three of these significant correlations more than $25 \%$ of the variability may be explained by concentration/dilution effects: $\mathrm{pH}$ (DP, $0.15 \mathrm{~m}$ soil depth), TOC (CE and DP, $0.3 \mathrm{~m}$ ). Thus, variations in water content only explained a small part of the variations in element concentrations during the monitored period. This was further confirmed by much higher element storages in the soil solution (water content $\times$ element concentrations) at the beginning of the rainy season than during the high rainy season (data not shown).

\section{CONCLUSIONS}

The grass biomass productivity of the regularly fertilized PP sites was twofold that of DP sites, which were only fertilized once about $13 \mathrm{yr}$ earlier. This seemed to be mainly the result of significantly higher plantavailable $\mathrm{Ca}, \mathrm{K}$, and $\mathrm{Mg}$ concentrations under PP than under DP. Thus, maintaining a constant productivity requires the regular application of $\mathrm{Ca}, \mathrm{K}$, and $\mathrm{Mg}$.

The effects of pasture use on chemical properties of the soil solid phase and soil solution are generally small when compared with effects of other permanent cultures on savanna Oxisols like Pinus plantations reported in the literature. The pasture soils show increased fertility compared with the CE because they store more $\mathrm{N}, \mathrm{S}$, $\mathrm{Ca}$, and $\mathrm{Mg}$ and show higher $\mathrm{K}, \mathrm{Ca}$, and $\mathrm{Mg}$ (only $\mathrm{PP}$ ) concentrations in the topsoil solution.

When the nutrient concentrations in soil solution at the 2-m depth are used as indication of the risk of nutrient losses to below the rooting zone, only $\mathrm{K}, \mathrm{Mn}$, and $\mathrm{N}$ are lost from both pastures and $\mathrm{Zn}$ from DP to a higher extent than under CE. The $\mathrm{Zn}$ losses under the PP are even lower than under CE. However, there may be a "first flush" effect at the beginning of the rainy season when all element concentrations are higher than during the high rainy season and when the pastures have a higher water content than the CE. This may result in more pronounced leaching losses of nutrients from the pasture soils with higher nutrient concentrations than from the $\mathrm{CE}$ soils which is probably particularly true for base metals under PP.

Our results demonstrate that both pasture systems may be considered as sustainable with respect to soil fertility although in DP grass biomass productivity was 

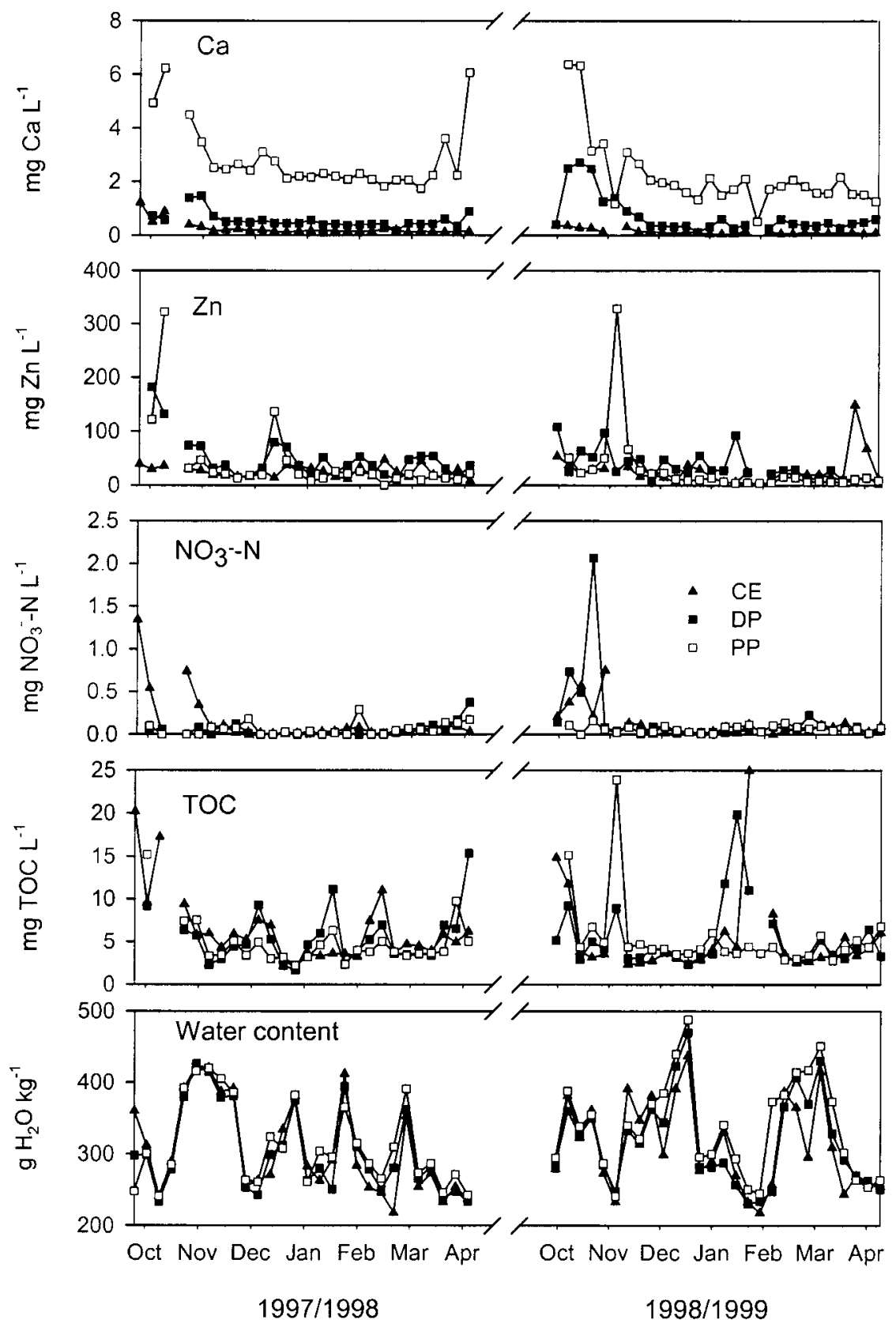

Fig. 4. Temporal course of $\mathrm{Ca}, \mathrm{Zn}, \mathrm{NO}_{3}-\mathrm{N}$, and total organic $\mathrm{C}$ (TOC) concentrations in soil solution and of soil water content at the 0.15-m depth of Cerrado (CE), degraded (DP), and productive pasture (PP) between 14 Oct. and 28 Apr. 1997-1998 and 1998-1999.

decreased and soil fertility partly had returned to the level of the native $\mathrm{CE}$.

\section{ACKNOWLEDGMENTS}

We thank M.C. de Aguiar, C. Benicke, H. Ciglasch, P.U. da Costa, A.C. Frascoli, T. Glotzmann, A. Hartmann, I. Lobe, M. Obst, A. Schill, U. Schwantag, A. Schwarz, L.S. Silva, and L.V.O. da Silva for their support. We also thank H.L.A. Bessa and C.R. Cage (Fazenda Planalto Hirofume), R. Domício (Fazenda Brasmix), J. Fonseca (Fazenda Rancharia Alegre), H. Fuzaro (Fazenda Passarinho), A.M.R. Lucinda and F.A.F. Neto (Fazenda Pinusplan), W. Ribeira da Sá (Fazenda Beija Flor), and A.F. Santos (Fazenda Estancia Recanto das Flores) for providing the study plots and for multiple help. We thank the Bayreuther Institut für Terrestrische Ökosystemforschung (BITÖK) for performing the $\mathrm{Al}, \mathrm{Mn}$, and $\mathrm{Zn}$ analyses. We are indebted to the German Research Foundation (DFG Ze 154/36-1,-2,-3: CE) and the MAS (Managing Acid Soils) program (DP, PP) convened by CIAT (Centro Internacional de la Agricultura Tropical, Cali, Colombia) for funding this study. Wolfgang Wilcke is working under a Heisenberg grant of the German Research Foundation (DFG Wi 1601/3-1), which is gratefully acknowledged.

\section{REFERENCES}

Birch, H.F. 1958. The effects of soil drying on humus decomposition and nitrogen availability. Plant Soil 10:9-31.

Boddey, R.M., B.J.R. Alves, and S. Urquiaga. 1996. Nitrogen cycling 
and sustainability of improved pastures in the Brazilian Cerrados. p. 33-38. In R.C. Pereira and L.C.B. Nasser (ed.) Proc. 1st International Symposium on Tropical Savannas. Empresa Brasileira de Pesquisa Agropecuária (EMBRAPA), Brasília-DF, Brazil.

Brümmer, G.W., J. Gerth, and U. Herms. 1986. Heavy metal species, mobility, and availability in soils. Z. Pflanzenernähr. Bodenkd. 149:382-398.

Cadisch, G., R.M. Schunke, and K.E. Giller. 1994. Nitrogen cycling in a pure grass pasture and a grass-legume mixture on a red latosol in Brazil. Trop. Grasslands 28:43-52.

Cahn, M.D., D.R. Bouldin, and M.S. Cravo. 1992. Nitrate sorption in the profile of an acid soil. Plant Soil 143:179-183.

Cerri, C.C., B. Volkoff, and F. Andreaux. 1991. Nature and behaviour of organic matter in soils under natural forest, and after deforestation, burning, and cultivation, near Manaus. For. Ecol. Manage. 38:247-257.

Currie, W.S., J.D. Aber, W.H. McDowell, R.D. Boone, and A.H. Magill. 1996. Vertical transport of dissolved organic N and C under long-term amendments in Pine and hardwood forests. Biogeochemistry 35:471-506.

Davis, J.A. 1982. Adsorption of natural organic matter at the oxide/ water interface. Geochim. Cosmochim. Acta 46:2381-2393.

Driessen, P.M., and R. Dudal. 1989. Lecture notes on the major soils of the world. Agricultural University Wageningen, The Netherlands, and Catholic University Leuven, Belgium.

Eden, M.J., P.A. Furley, D.F.M. McGregor, W. Miliken, and J.A. Ratter. 1991. Effect of forest clearance and burning on soil properties in northern Roraima, Brazil. For. Ecol. Manage. 38:283-290.

Feigl, B.J., J. Melillo, and C.C. Cerri. 1995. Changes in the origin and quality of soil organic matter after pasture introduction in Rondônia (Brazil). Plant Soil 175:21-29.

Friesen, D.K., I.M. Rao, R.J. Thomas, A. Oberson, and J.I. Sanz. 1997. Phosphorus acquisition and cycling in crop and pasture systems in low fertility tropical soils. Plant Soil 196:289-294.

Goedert, W.J. 1983. Management of the Cerrado soils in Brazil: A review. J. Soil Sci. 34:405-428.

Gu, B., J. Schmitt, Z. Chen, L. Liang, and J.F. McCarthy. 1994. Adsorption and desorption of natural organic matter on iron oxide: Mechanisms and models. Environ. Sci. Technol. 28:38-46.

Hartung, J. 1989. Statistik. (In German.) Oldenbourg-Verlag, München, Germany.

Hartung, J., and B. Elpelt. 1989. Multivariate Statistik. (In German.) Oldenbourg-Verlag, München, Germany.

Holmgren, G.G.S. 1967. A rapid citrate-dithionite-extractable iron procedure. Soil Sci. Soc. Am. Proc. 31:210-211.

Hölscher, D. 1995. Wasser- und Stoffhaushalt eines Agrarökosystems mit Waldbrache im östlichen Amazonasgebiet. (In German.) Göttinger Beiträge zur Land-und Forstwirtschaft in den Tropen und Subtropen 106:134.

Jardine, P.M., and L.W. Zelazny. 1996. Surface reactions of aqueous aluminum species. p. 221-270. In G. Sposito (ed.) The environmental chemistry of aluminum. CRC Press, New York.

Jordan, C.F. 1982. The nutrient balance of an Amazonian rain forest. Ecology 63:647-654.

Kalbitz, K., S. Solinger, J.H. Park, B. Michalzik, and E. Matzner. 2000. Controls on the dynamics of dissolved organic matter in soils: A review. Soil Sci. 165:277-304.

Kornelius, E., M.G. Saueressig, and W.J. Goedert. 1979. Pastures establishment and management in the Cerrado of Brazil. p. 147175. In P.A. Sánchez and L.E. Tergas (ed.) Pasture production in acid soils of the tropics. Centro Internacional de Agricultura Tropical (CIAT), Cali, Columbia.

Koutika, L.-S., F. Bartoli, F. Andreux, C.C. Cerri, G. Burtin, T. Choné, and R. Philippy. 1997. Organic matter dynamics and aggregation in soils under rain forest and pastures of increasing age in the eastern Amazon basin. Geoderma 76:87-112.

Lilienfein, J., W. Wilcke, H. Neufeldt, M.A. Ayarza, and W. Zech. 1998. Land-use effects on organic carbon, nitrogen, and sulphur concentrations in macroaggregates of differently textured Brazilian Oxisols. Z. Pflanzenernähr. Bodenkd. 161:165-171.

Lilienfein, J., W. Wilcke, M.A. Ayarza, S.d.C. Lima, L. Vilela, and W. Zech. 1999. Annual course of matric potential in differently used savanna Oxisols in Brazil. Soil Sci. Soc. Am. J. 63:1778-1785.

Lilienfein, J., W. Wilcke, M.A. Ayarza, L. Vilela, S.d.C. Lima, and
W. Zech. 2000a. Soil acidification in Pinus caribaea forests on Brazilian savanna Oxisols. For. Ecol. Manage. 128:145-157.

Lilienfein, J., W. Wilcke, M.A. Ayarza, L. Vilela, S.d.C. Lima, and W. Zech. 2000b. Chemical fractionation of phosphorus, sulphur, and molybdenum in Brazilian savannah Oxisols under different land use. Geoderma 96:31-46.

Lilienfein, J., W. Wilcke, L. Vilela, S.d.C. Lima, R. Thomas, and W. Zech. 2001a. Effects of Pinus caribaea plantations on the C, N, P, and S status of Brazilian savanna Oxisols. For. Ecol. Manage. 147:171-182.

Lilienfein, J., W. Wilcke, R. Zimmermann, P. Gerstberger, G.M. Araújo, and W. Zech. 2001b. Nutrient storage in soil and biomass of native Brazilian Cerrado. J. Plant Nutr. Soil Sci. 164:487-495.

Lopes, A., M. Ayarza, and R. Thomas. 1999. Sistemas agropastoriles en las sabanas de América Latina tropical: Lecciones del desarollo agrícola de los Cerrados de Brasil. (In Spanish.) p. 9-30. In E.P. Guimaraes et al. (ed.) Sistemas agropastoriles en sabanas tropicales de América Latina. Centro Internacional de Agricultura Tropical (CIAT), Cali, Colombia and Empresa Brasileira de Pesquisa Agropecuária (EMBRAPA), Brasília-DF, Brazil.

Matzner, E., and E. Thoma. 1983. Auswirkungen eines saisonalen Versauerungsschubes im Sommer/Herbst auf den chemischen Bodenzustand verschiedener Waldökosysteme. (In German.) Allg. Forstz. 39:677-683.

McKnight, D.M., K.E. Bencala, G.W. Zellweger, G.R. Aiken, G.L. Feder, and K.A. Thorn. 1992. Sorption of dissolved organic carbon by hydrous aluminum and iron oxides occurring at the confluence of Deer Creek with Snake River, Summit County. Colorado. Environ. Sci. Technol. 26:1388-1396.

Morais, F.I., A.L. Page, and L.J. Lund. 1976. The effect of pH, salt concentration, and nature of electrolytes on the charge characteristics of Brazilian tropical soils. Soil Sci. Soc. Am. J. 40:521-527.

Nepstad, D.C., C.R. de Carvalho, E.A. Davidson, P.H. Jipp, P.A. Lefebvre, Gustavo H. Negreiros, E.D da Silva, T.A. Stone, S.E. Trumbore, and S. Vieira. 1994. The role of deep roots in the hydrological and carbon cycles of Amazonian forests and pastures. Nature 372:666-669.

Neufeldt, H. 1998. Land-use effects on soil chemical and physical properties of Cerrado Oxisols. Bayreuther Bodenkundliche Berichte 59. Institute of Soil Science and Soil Geography, University of Bayreuth, Bayreuth, Germany.

Resck, D.V.S., C.A. Vasconsellos, L. Vilela, and M.C.M. Macedo. 2000. Impact of conversion of Brazilian Cerrados to cropland and pastureland on soil carbon pool and dynamics. p. 169-196. In R. Lal, J.M. Kimble, and B.A. Stewart (ed.) Global climate change and tropical ecosystems. Adv. Soil Sci., CRC Press, Boca Raton, FL.

Rosa, R., S.d.C. Lima, and W.A. Assunção. 1991. Abordagem preliminar das condições climáticas de Uberlândia (MG). (In Portuguese.) Federal University of Uberlândia, Uberlândia, Brazil. Sociedade e Natureza 3:91-108.

Sarmiento, G. 1984. The ecology of neotropical savannas. Harvard University Press. Cambridge.

Savory, J., and M.R. Wills. 1991. Aluminum. p. 715-741. In E. Merian (ed.) Metals and their compounds in the environment. VCH, Weinheim, Germany.

Schroth, G., L.F.d. Silva, R. Seixas, W.G. Teixeira, J.L.V. Macêdo, and W. Zech. 1999. Subsoil accumulation of mineral nitrogen under polyculture and monoculture, fallow, and primary forest in a ferralitic Amazonian upland soil. Agric. Ecosyst. Environ. 1467:1-12.

Schwertmann, U. 1964. Differenzierung der Eisenoxide des Bodens durch Extraktion mit Ammoniumoxalat-Lösung. (In German, with English abstract.) Z. Pflanzenernähr. Düng. Bodenkd. 105:194-202.

Soil Survey Staff. 1997. Keys to Soil Taxonomy, 7th ed. SMSS technical monograph No. 19, Pocahontas Press, Blacksburg, VA.

Sørensen, L.H. 1974. Rate of decomposition of organic matter in soil as influenced by repeated air drying-rewetting and repeated additions of organic material. Soil Biol. Biochem. 6:287-292.

Spain, J.M., M.A. Ayarza, and L. Vilela. 1996. Crop pasture rotations in the Brazilian Cerrados. p. 39-45. In R.C. Pereira and L.C.B. Nasser (ed.) Proc. 1st International Symposium on Tropical Savannas. Empresa Brasileira de Pesquisa Agropecuária (EMBRAPA), Brasília-DF, Brazil.

Steinhardt, U. 1979. Untersuchungen über den Wasser- und Nährstoffhaushalt eines andinen Wolkenwaldes in Venezuela. (In German.) 
Göttinger Bodenkundliche Berichte 56, University of Göttingen, Germany.

Sumner, M.E., and W.P. Miller. 1996. Cation-exchange capacity and exchange coefficients. p. 1201-1229. In D.L Sparks et al. (ed.) Methods of Soil Analysis. Part 3. SSSA Book Ser. 5. SSSA, Madison, WI.

Tiessen, H., and J.O. Moir. 1993. Characterization of available P by sequential extraction. p. 75-86. In M.R. Carter (ed.) Soil sampling and methods of analysis. CRC Press, Boca Raton, FL.

Uhl, C., and C.F. Jordan. 1984. Succession and nutrient dynamics following forest cutting and burning in Amazonia. Ecology 65:1476-1490.

Ulrich, B. 1981. Ökologische Gruppierung von Böden nach ihrem chemischen Bodenzustand. (In German, with English abstract.) Z. Pflanzenernähr. Bodenkd. 144:289-305.

Vance, G.F., F.J. Stevenson, and F.J. Sikora. 1996. Environmental chemistry of aluminum-organic complexes. p. 169-220. In G. Sposito (ed.) The environmental chemistry of aluminum. Lewis Publishers, Boca Raton, FL.

Whiteman, P.C., S.A. Waring, E.S. Wallis, and L.C. Bruce. 1980 Tropical pasture science. Oxford University Press, New York.

Reprinted with permission from Soil Science Society of America. Originally published in Soil Science Society Journal 67(4):1195-1205, Copyright 2003. 